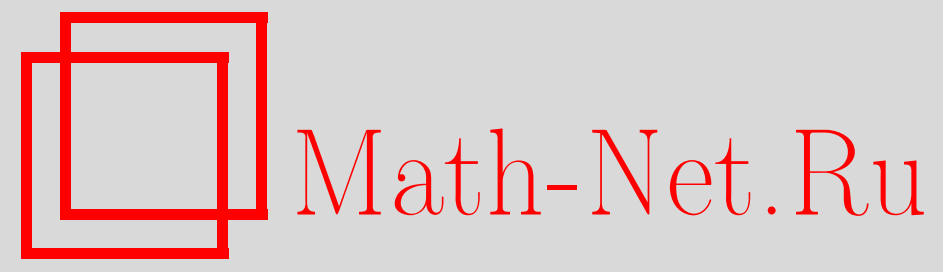

Г. И. Фалин, А. С. Черный, Информация о работе большого семинара кафедры теории вероятностей механикоматематического факультета МГУ, Теория вероятн. и ее примен., 2000, том 45, выпуск 3, 622

DOI: https://doi.org/10.4213/tvp494

Использование Общероссийского математического портала Math-Net.Ru подразумевает, что вы прочитали и согласны с пользовательским соглашением http://www.mathnet.ru/rus/agreement

Параметры загрузки:

IP : 44.207 .124 .84

26 апреля 2023 г., $17: 47: 12$

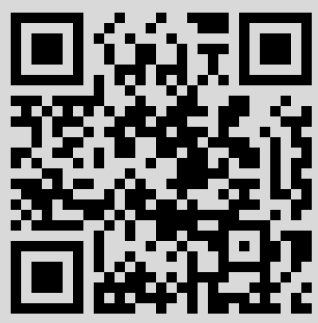




\section{ИНФОРМАЦИЯ О РАБОТЕ БОЛЬШОГО СЕМИНАРА КАФЕДРЫ ТЕОРИИ ВЕРОЯТНОСТЕЙ МЕХАНИКО-МАТЕМАТИЧЕСКОГО ФАКУЛЬТЕТА МГУ}

В весеннем семестре 2000 года были представлены доклады по следующим темам: теория диффузионных процессов и стохастические дифференциальные уравнения, статистический анализ фннансовых данных, математическая теория надежности, статистика случайных процессов. Ниже приводится полный список докладов. (Информацию о предшествуюших докладах см. в т. 44, в. 3; т. 45, в. 1.)

16 февраля - А.В. Летчиков (Ижевск). Устойчиость произведекиน̆ независиных случайных матрич.

23 февраля - А.В. Колногоров (Новгород). Алгоритм отьскакия мияимахскых стратегий и риска для бернуллиевского «двурухого бандита».

1 марта - А. Ю. Веретенников (Москва). Об одной задаче аппрохсимачиน для стохастических дифферекчиалькых уравкекий.

15 марта - В. К. Богачев (Москва). Инвариантные меры диффузионяьх прочессов: проблемы регулярности, сучествования и единствеккости.

22 марта - Я. И. Белопольскаа (Санкт-Петербург). Многомерные уравкения Бюргерса, Риккати и Кортевега-де Фриза в теории дифФузионных прочессов.

22 марта - А. А. Гущин (Москва). Диапазоя чен опчиоков и сравкекие эхспериментов.

5 апреля - А. Д. Соловьев (Москва). Некоторые керешекные задачи математической теории надежности.

12 апреля - В.Н. Тутубалин (Москва). Cтохастическая финансовая математика на российской почве.

19 апреля - М.Л. Клепцына (Москва). Формула Камерома-Мартияа для произвольного гауссовского прочесса.

26 апреля Большой кафедральный семинар не собирался в связи с проведением в Москве международной конференции «Колмогоровские итения-2000».

10 мая - А. С. Черный (Москва). Доклад-представление диссертационной работы «Качественное поведение речекий стохастических дифференциальных уравнекий с сикәулярными коэффичиектами» на соискание ученой степени кандидата физико-математических наук.

Координатор семинара в весеннем семестре 2000 года профессор Г. И. Фалин Ученый секретарь А.С. Черный 